\title{
Nevrasteni i Norge 1880-1920
}

\begin{abstract}
SAMMENDRAG
Nevrasteni som diagnostisk kategori ble lansert i Amerika i 1869 og spredte seg raskt til Europa. Flere har trukket paralleller mellom den historiske sykdomsenheten nevrasteni og nåtidige tilstander som kronisk utmattelsessyndrom/myalgisk encefalopati og utbrenthet, men lite er kjent om nevrasteniens tidlige historie i Norge. Med utgangspunkt i norske fagmedisinske tidsskrifter fra perioden 1880-1920 har vi ønsket å studere innføringen, forståelsen og anvendelsen av nevrastenibegrepet i norsk medisin, med særlig vekt på symptomer, årsaker, behandling, prognose og utbredelse.
\end{abstract}

Resultatene viser at termen trolig ble anvendt første gang i et norsk medisinsk tidsskrift i 1876, og utover 1880-årene rapporteres det om stadig flere som ble diagnostisert med nevrasteni. Tilstanden ble definert som en svekkelse av nervesystemet. Symptombildet var omfattende, med utmattelse som hovedsymptom. Symptomenes årsaker kunne ikke verifiseres eller lokaliseres objektivt, og teoriene var mange. Overanstrengelse var en vanlig forklaring, men også traumer, infeksjoner, feil kosthold, arv og seksuelle utskeielser var antatte årsaker. Den anbefalte behandlingen dreide seg om å styrke nervesystemet, blant annet gjennom hvile og elektrifisering. Tilstanden ble beskrevet som typisk for sin tid, som en respons på «tidsånden» og det moderne liv.

"Fortjener nogen Sygdom Navn af 'Nutidssygdom', saa er det vel Neurastenien.» (1)

Dette sitatet fra 1886 mer enn antyder at nevrasteni i løpet av 1880-årene ikke bare var en sykdom som stadig bredte om seg, det peker også mot en tilstand som ble betraktet som typisk for sin tid, en sykdom som altså både mange ble rammet av og som kunne knyttes til spesifikke kjennetegn ved samtiden. Da sitatet sto på trykk i Norsk Magazin for Lagevidenskaben i 1886, var termen nevrasteni (av gr. nervesvakhet) ganske nylig introdusert i Norge. Nevrasteniens «fødsel» som medisinsk kategori dateres som oftest til 1869 , og det er den amerikanske nevrologen George M. Beard (1839-83) som i ettertid har fătt æren for å ha lansert diagnosen (2). Beard mente at nevrasteni var en fysisk sykdom som skyldtes bortfall av nerveenergi, og han oppfattet tilstanden som en respons på den moderne sivilisasjonens raske fremvekst og rivende utvikling på en rekke fronter (3). Nevrasteni ble først oppfattet som en sykdom som var spesifikt knyttet til den amerikanske kulturen, men diagnosen spredte seg raskt og kom til Europa tidlig i 1880 -årene (4).

Selv om nevrasteni hadde sin «gullalder» som sykdom og medisinsk kategori i USA og Europa de siste tiårene av 1800-tallet og litt inn på 1900-tallet, har begrepet relevans også i vår tid. Kategorien finnes fremdeles i enkelte diagnosesystemer, som i ICD-10, der den er klassifisert som en nevrose (F48.0) (5). Dessuten er 1800-tallets nevrasteni blitt beskrevet som en mulig forløper til syndromer vi i dag kjenner som kronisk utmattelsessyndrom/myalgisk encefalopati (CFS/ME), utbrenthet m.fl. Dette er blant annet blitt begrunnet med at det finnes likhetstrekk i symptombildet og årsaksforklaringer mellom disse nåtidige syndromene og 1800-tallets nevrasteni $(4,6)$. Andre har vist til parallelle trekk ved samfunnsutviklingen under de aktuelle tidsepokene som kategoriene har oppstått i (7).

Vårt formål er ikke å påstå noe om hva sykdomsenheten nevrasteni egentlig var eller er i biomedisinsk forstand, eller hvorvidt det er/ikke er biomedisinske eller andre paralleller mellom den historiske tilstanden nevrasteni og nåtidige tilstander. Vi ønsker å kaste lys over nevrasteniens tidlige historie i Norge, som så langt har vært lite studert. Mer spesifikt tar vi i denne artikkelen for oss innføringen, forståelsen og anvendelsen av nevrastenibegrepet i norsk medisin i årene 1880-1920, slik det fremgår av fagmedisinske tidsskrifter fra perioden. Vi søker å svare på følgende spørsmål: Når kom nevrastenibegrepet i bruk i norske medisinske tidsskrifter? Hvordan artet tilstanden seg? Hvilken forståelse av årsaker og behandling var toneangivende? Hvordan var prognosen, og hvor utbredt var tilstanden?

\section{Kunnskapsgrunnlag}

Som materiale har vi valgt ut samtlige tekster som omhandler nevrasteni i de tre tidsskriftene Norsk Magazin for Lagevidenskaben, Tidsskrift for Praktisk Medicin (fra 1889 Tidsskrift for Den norske lageforening) og Medicinsk Revue fra perioden 1880-1920. Termen nevrasteni opptrer
Kristine Lillestøl

kristine.lillestol@medisin.uio.no Hilde Bondevik

Avdeling for samfunnsmedisin Institutt for helse og samfunn Universitetet i Oslo

\section{HOVEDBUDSKAP}

I 1880-årene ble nevrasteni en stadig hyppigere anvendt diagnostisk kategori i Norge, særlig på kur- og badeanstalter

Symptombildet var omfattende, med utmattelse som hovedsymptom

Overanstrengelse var en vanlig forklaring, men også traumer, infeksjoner, feil kosthold, arv og seksuelle utskeielser var antatte årsaker

Hvile, isolasjon, massasje, elektroterapi, arbeidsterapi, diett og bad var viktige elementer $\mathrm{i}$ behandlingen

Både kvinner og menn ble rammet av tilstanden 


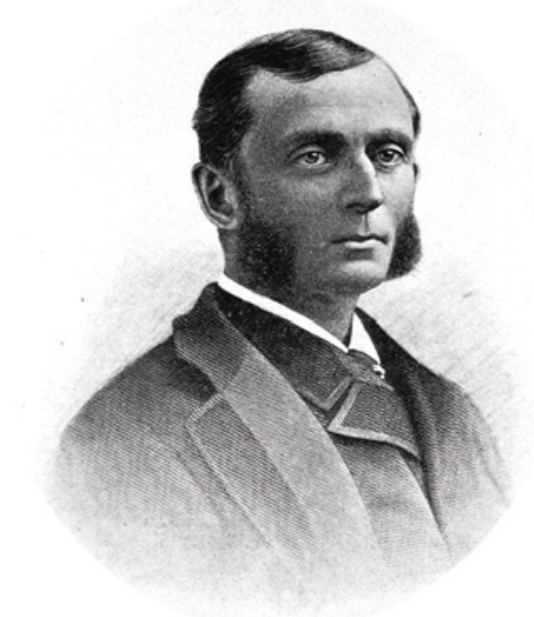

George Miller Beard, Wikimedia Commons

svært sjelden i tidsskriftenes registre, så nærlesing av de enkelte tidsskriftene har vært påkrevd for å finne alt relevant materiale. Nevrasteni er i tidsskriftene omtalt i både artikler, bokanmeldelser, oversatte notiser fra utenlandske tidsskrifter og innberetninger fra ulike norske sykehus og kur- og badeanstalter. Sammenliknet med andre medisinske tilstander og aktuelle profesjonsspørsmål i denne perioden fikk tilstanden likevel lite spalteplass samlet sett.

\section{Nevrastenien introduseres}

Nevrasteni som begrep og diagnose ble trolig første gang brukt $i$ et norsk medisinsk tidsskrift i 1876 (8), men ble ikke et vanlig tema før i 1880-årene. Første gang diagnosen ble anvendt $i$ de trykte beretningene fra kur- og badesteder var i beretningen fra Laurviks bad fra årene 1880-82 (9). Deretter inngikk nevrasteni som diagnostisk kategori i stadig flere kur- og badeberetninger, og fra 1885 kom flere og mer utfyllende beskrivelser av tilstanden. De norske legene var i sine første beskrivelser særlig påvirket av tyske leger, som hadde vært tidlig ute med å oversette Beards skrifter om nevrasteni $(1,10,11)$.

Men var nevrastenien egentlig noen ny tilstand? Enkelte mente at den var «et barn af den moderne maade at leve paa», som man ikke kunne finne omtalt i eldre lærebøker (12). Flere sluttet seg imidlertid til oppfatningen av at «Neurasteni er et nyt Navn på en gammel Sygdom» (13). Nomenklaturen gjennom den undersøkte perioden var heller ikke helt konsistent. Eksempelvis ble «Nervøsitet og Neurastheni» anvendt samlet som en kategori i Treaars-Beretning fra Hankø Bad og Kystsanatorium (1882-84) (14). Før introduksjonen av nevrastenibegrepet ser det ut til at det særlig var betegnelsene «nervesvækkelse» og «nervøs debilitet» som ble anvendt som navn på tilsvarende symptombilde. I en periode ble flere av betegnelsene også brukt om hverandre.

\section{Det kliniske bildet}

«En udtømmende Beskrivelse af Neurasteniens Symptomer vilde kræve et Bind,» konstaterte signaturen St. i 1885 (13) og hadde nok rett $\mathrm{i}$ det. Beard inkluderte 50-100 symptomer i sine opprinnelige beskrivelser av tilstanden $(2,3)$, og også i norske artikler ble det listet opp lange rekker av plager som kunne være forenlige med nevrasteni. Særlige kjennetegn var likevel en uttalt utmattelse og tretthet som ikke ble bedret av vanlig nattesøvn, samt at mange av plagene ble forverret ved mental eller fysisk anstrengelse $(12,13$, 15). Blant hyppig ledsagende symptomer var hodepine, søvnløshet, irritabelt humør, mageplager, parestesier, nevralgier, rykninger, kalde ekstremiteter, øresus, hjertebank, angst og nedstemthet, for å nevne noen $(12,13)$. Nevrastenikere hadde altså ikke bare symptomer forbundet med en generell svekkelse, de hadde også symptomer som kunne tyde på økt irritabilitet eller «pirrelighet» av nervesystemet (ofte referert til som «reizbare Schwäche») (15, 16). Forløpet var svingende, og nevrastenikerne kunne beskrives som «engle eller dæmoner, alt eftersom de er udhvilte eller deres kræfter er udtømte» (15).

Pasienter med et begrenset symptombilde kunne få en noe mer presis diagnose basert på symptomenes lokalisasjon, som for eksempel spinal, cerebral, seksuell eller gastrisk nevrasteni (12). I den tidligste referansen til nevrasteni i dette materialet var det den cerebrale varianten som ble omtalt, men senere var det særlig gastrisk nevrasteni som fanget de norske legenes oppmerksomhet. «Nervøse maveaffektioner» var blant de hyppigst forekommende symptomene ved nevrasteni, både i form av økt irritabilitet av mage-tarm og i form av «svekkelsessymptomer» som nedsatt tarmmotilitet (17). Også seksuell nevrasteni ble beskrevet, med «pollutioner», impotens og spermatoré som fremtredende symptomer $(12,13)$.

En utfordring ved diagnostisering av nevrasteni var fravær av spesifikke patologiske funn, både på mikro- og makroskopisk nivå. En generell klinisk undersøkelse viste som regel ingen avvik som kunne gi støtte til diagnosen (13). Grenseoppgangene mot andre tilstander kunne derfor være krevende, og særlig måtte man være oppmerksomme på differensialdiagnoser som Basedows sykdom, revmatiske lidelser, melankoli/depresjon og initialstadier av alvorligere sinnslidelser som dementia praecox $(10,15)$. Grensen mellom nevrasteni og diagnoser som hysteri og klorose var også svært utydelig - i hvert fall før århundreskiftet. I et foredrag om nervøsitet fra 1891 sa Edvard Bull (1845-1925) at nevrasteniens område ikke lar seg skarpt avgrense «oppad eller nedad», og at denne umerkelig kan gli over «i Sindssygdommene, i Hysteri, Hypokondri og andre bestemte Nervesygdomme, der ligesom udvikler sig paa Neurasteniens Jordbund» (18).
Til tross for slike uklare grenser fremstår det kliniske bildet som ganske tydelig gjennom perioden som materialet favner, og de fleste legene oppfattet tilstanden som en virkelig, selvstendig sykdom $(13,19)$.

\section{Årsaker}

Også av norske leger ble symptomene oppfattet som uttrykk for en svekkelse av nervesystemet. De eksakte patofysiologiske mekanismene for denne svekkelsen var ukjente, men det var en utbredt forestilling at ernæringsanomalier i nervesystemet spilte en vesentlig rolle $(13,16)$. På et overordnet nivå ble nevrasteni forklart som et produkt av samtiden, med sin «forcerede Kamp for Tilværelsen og sin Nydelsessyge, hvor alle Aarer lægges ud for hurtigst mulig at naa det mest mulige» (19), og overanstrengelser av ulike slag ble regnet som den vanligste utløsende årsaken (16). Ragnar Vogt (1870-1943), Norges første professor i psykiatri, fremhevet særlig uforholdsmessig sterke krav til hjernearbeid som en hovedårsak (15).

Andre former for overanstrengelser som også kunne forårsake nevrasteni, var et «forceret selskabsliv», tungt kroppsarbeid eller overtrening. Johan Peter Torgersen (1875-1919), lege og trener i Norske Studenters Roklub, hadde for eksempel observert flere tilfeller av langvarig nevrasteni som følge av intensiv opptrapping av trening like før mesterskap (20). Hos kvinner var mange og tett påfølgende svangerskap en mulig utløsende faktor (21). Særlig stor risiko for å utvikle nevrasteni hadde de som var utsatt for flere former for overanstrengelse samtidig, som «alle de folk, hvis virksomhed ikke blot forlanger et energisk arbeide, men ogsaa ofte medfører gemytsbevægelser (som lærde, kunstnere, børsmænd, spekulanter, politikere)» (12).

Misbruk av «gifter» som alkohol, tobakk og kaffe samt mangelfull eller feil ernæring var andre hyppig nevnte årsaker til nevrasteni (13). Særlig ble «det moderne kulturmenneskets overdrevne nydelse af eggehvide» - altså et proteinrikt kosthold - fremstilt som uheldig (22). Flere forfattere mente også at nevrasteni kunne oppstå som følge av at giftige produkter fra gjærings- og forråtnelsesprosesser i tarmene går over i blodet, såkalt intestinal autointoksikasjon (23).

Et nevrasteniliknende sykdomsbilde kunne også opptre i kjølvannet av infeksjonssykdommer som kolera, tyfus og influensa, særlig hvis rekonvalesensfasen ble avbrutt for tidlig $(15,24)$. Av og til ble nevrasteni satt i sammenheng med anemi eller bleksott og klorose, men anemi ble likevel ikke betraktet som en nødvendig forutsetning for at nevrasteni skulle oppstå $(9,13)$.

For undergruppen seksuell nevrasteni gjaldt egne årsaksforklaringer, som avbrutt samleie, onani, og andre «perversiteter i kjønsdriften» (12). En annen undergruppe med spesifikke utløsende årsaker var trau- 
matisk nevrasteni, som for eksempel kunne oppstå etter støt mot hodet (15).

Med utbruddet av første verdenskrig ble søkelyset også rettet mot andre former for traumer, og krigens betydning for utviklingen av ulike sinnslidelser ble diskutert. Ifølge Vogt kunne soldatenes kroppslige og sjelelige overanstrengelser i krigens strabaser føre til utvikling av nevrasteniske symptomer som trettbarhet, irritabilitet, sviktende konsentrasjon og dårlig søvn (25). Noen mente at offiserer var mer utsatt for å utvikle nevrasteniske lidelser enn soldater for øvrig, blant annet på grunn av offiserenes finere differensierte hjerne (26).

I tillegg til alle disse «eksogene» formene for nevrasteni, som ble antatt å være forårsaket av ytre faktorer, ble også en «endogen», arvelig form beskrevet, der lidelsen ble oppfattet som et utslag av psykisk degenerasjon $(24,27)$. Flere understreket at det gikk et tydelig skille mellom arvelig og ervervet nevrasteni, og enkelte hevdet at den ervervede var den «egentlige» nevrastenien (15).

\section{Behandling}

De overordnede målene for behandlingen av nevrasteni var å styrke nervesystemet og å fjerne eventuelle utløsende årsaker. Hvile, ro og skjerming fra dagliglivets anstrengelser og bekymringer, endring av usunne vaner og bedring av ernæringstilstanden ble dermed essensielle elementer i terapien (13, 16). Internasjonalt var det særlig den amerikanske nevrologen Silas Weir-Mitchell (1829-1914) som ble kjent for å ha satt denne behandlingen i system, og hans mye omtalte hvilekur var også velkjent blant norske leger. I tillegg til mye hvile og isolasjon besto denne kuren av en næringsrik diett, massasje og elektroterapi, i et individuelt tilpasset regime (13).

Weir-Mitchells anbefalte diett hadde oppforing som formål og besto av rikelig melk og ellers kraftig, fet kost (28). Såkalte «melkekurer» ble også anbefalt ved enkelte norske kursteder, som ved Dr. Torps Sygehjem for Nervesvækkede på Lillehammer (27), mens andre leger foretrakk vegetarisk diett (22).

Både massasje og elektroterapi ble antatt å kunne bedre pasientenes næringsopptak (13). Mens Weir-Mitchell regnet elektroterapi som det minst viktige elementet $i$ hvilekuren, anbefalte Beard «almindelig Elektrisation» som en av de viktigste behandlingsformene ved nevrasteni $(2,29)$. I Norge ble elektriske bad tidlig innført ved enkelte kursteder, som badene i Modum og Sandefjord $(29,30)$. Bedre søvn, lavere pulsfrekvens, et mer regelmessig avføringsmønster og generelt en forfriskende og opplivende følelse, var blant de gunstige virkningene av slike bad. Men til tross for gode tilbakemeldinger fra pasienter var effekten av elektroterapien omdiskutert blant legene. Flere mente at en gunstig effekt av elektrisiteten

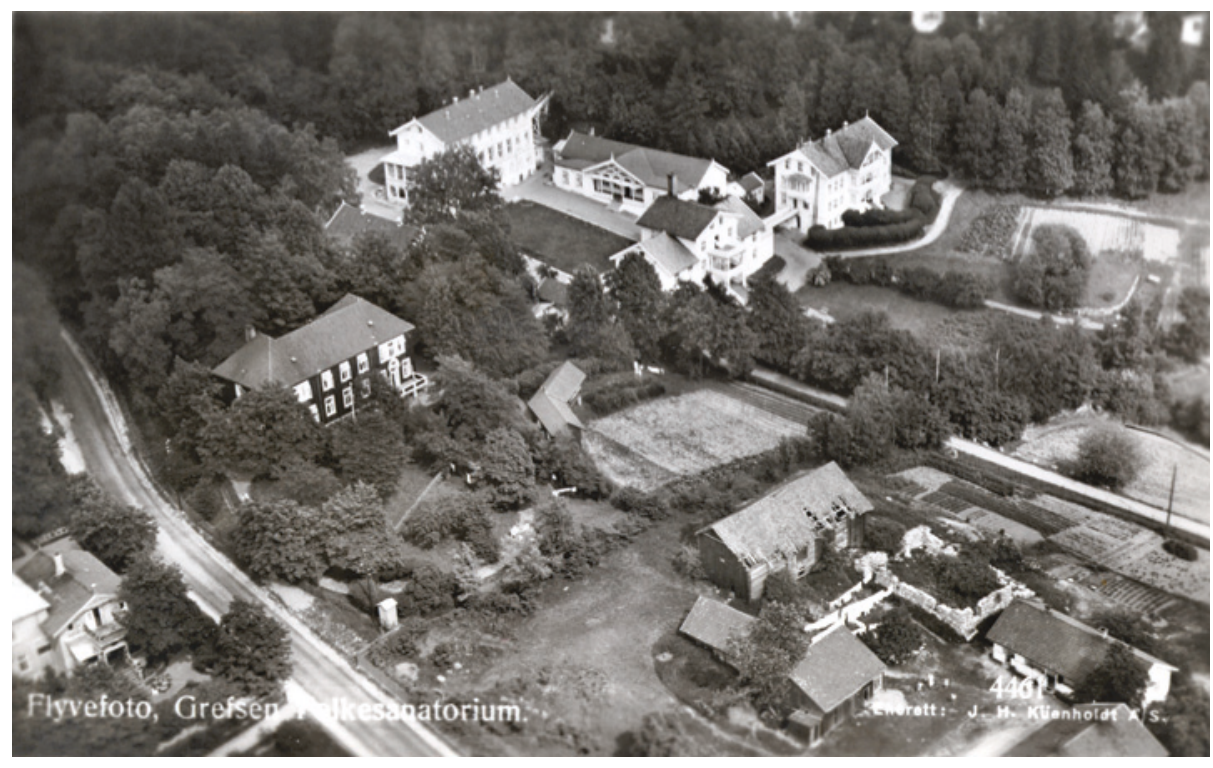

Grefsen sanatorium. Postkort fra J.H. Küenholdt, 1920-årene/Oslo Museum

som sådan ikke kunne bevises og at de positive virkningene av elektroterapien hovedsakelig skyldtes «suggestion», altså pasientens tro på at behandlingen virket (16).

Den vesentligste delen av badeterapien ved norske kuranstalter var likevel av ikkeelektrisk natur. Anbefalingene for nevrastenikere varierte. Ingebrigt Christian Lund Holm (1844-1918) ved Laurviks bad anbefalte tempererte eller kalde furunålsbad, mens Hans Gabriel Sundt Dedichen (1836-99) ved Modum anbefalte hudirriterende midler som frottering, massasje, børsting og pisking i tilslutning til badingen $(9,19)$.

I tillegg til slike spesifikke kurmidler var også beliggenheten til de enkelte kuranstaltene av betydning. Klimatiske forhold ble antatt å kunne påvirke både stoffskifte, sirkulasjon, ernæring og «nerveliv» og kunne dermed forbedre og eventuelt forverre sykdom. Holm, som var en spesielt ivrig talsmann for vitenskapelig bruk av klimatoterapi i Norge, fremhevet særlig tre klimatiske faktorer som viktige når man skulle velge kursted for en pasient: Høyde over havet, avstand fra havet og vegetasjon. For nevrastenikere anbefalte han spesielt opphold i subalpint (300-700 m.o.h.) skogklima, som skulle virke beroligende, men også kunne ha en viss «inciterende» virkning på nervesystemet (31).

Selv om hvile var et kjerneelement ved kuroppholdene, ble fullstendig inaktivitet over lengre tid frarådet i de fleste tilfeller, blant annet for å unngå tvangstanker, «hypokondrisk selviagttagelse» og derav følgende symptomforsterkning $(15,32)$. Lett praktisk arbeid, som hagearbeid og snekring, ble ofte anbefalt, særlig for dem som var utmattet på grunn av ensidig hjernearbeid over tid. Forsiktig mosjon ble også foreskrevet, og den danske legen Frode Sadolin (1866-1951) anbefalte særlig fotturer i behandlingen av nevrasteni: «At hjernen ligger brak, mens benene er i bevægelse, er lige det modsatte af moderne kulturliv, det kan derfor være et tjenligt skifte for kulturens invalider» (32). Mange av kurstedene la også opp til andre former for atspredelse for nevrasteniske pasienter, som ved Dr. Torps Sygehjem, der pasientene ble samlet til selskapelig underholdning hver kveld: «Aviser læses, schak og kort spilles, og en gang imellem faar man sig en liden dans for at lette barometerstanden» (27).

For den øvrige «psykiske» behandlingen av nevrasteni ble legens rolle fremhevet som særlig viktig: «Man maa taalmodig høre paa den syge, atter og atter forestille ham, at alle hans organer anatomisk er sunde, og at det kun dreier sig om en nervøs overanstrengelse, om et deficit i nervekraften. Til en saadan behandling hører imidlertid god tid, og den læge, som ikke kan ofre litt tid paa saadanne patienter, bør slet ikke befatte sig med dem» (12). Av mer spesifikke former for psykoterapi ble hypnose kort nevnt, etter århundreskiftet også psykoanalyse, men ingen av disse fikk mye omtale i nevrastenisammenheng $(28,33)$. For øvrig ser det ut til at et mindre antall nevrastenikere ble behandlet ved sinnssykeasylene. I perioden 1910-15 hadde overlege Harald Arnesen (1862-1963) ved Valen asyl 61 pasienter innlagt under diagnosekategorien «Konstitutionel sindssygdom», som blant annet omfattet diagnosen «insania neurasthenica» (34). Antakelig var dette spesielt uttalte tilfeller av tilstanden, da nevrasteni av flere ble regnet som en lettere «sindssvækkelse» og ikke som en egentlig sinnssykdom (15).

Nytten av medikamenter i behandlingen av nevrasteni var omdiskutert. Noen leger anbefalte liberal bruk av preparater som arsenikk, belladonna, valeriana, opium, kodein, stryknin og kinin (16). Andre oppfordret til restriktiv bruk, siden medikamen- 


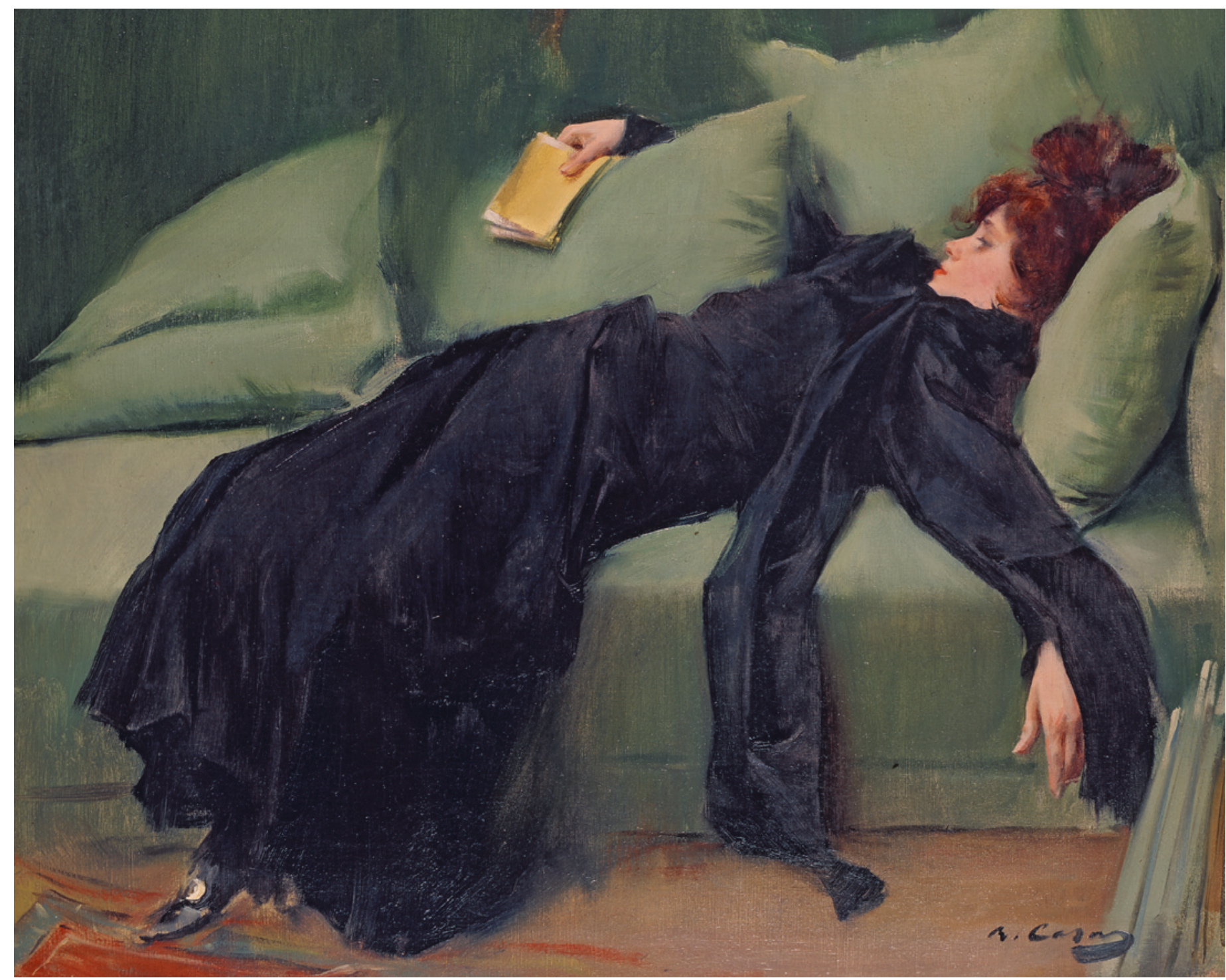

After the dance av Ramón Casas (1866-1932), olje på lerret. Museu de Montserrat, donert av J. Sala i Ardiz

ter kun virket symptomlindrende og nevrastenikere hadde økt risiko for å utvikle avhengighet $(13,15,27)$. Det ble ellers gjort mer og mindre seriøse forsøk på å fremstille medikamenter som ikke bare virket symptomlindrende, men som også skulle bedre selve grunntilstanden gjennom å styrke nervesystemet. Blant de seriøse aktørene var den franske nevrologen Charles Édouard Brown-Séquard (1817-94). Han interesserte seg særlig for den opplivende virkningen ekstrakter fra ulike dyrs testikler kunne ha på utmattede mennesker, og utførte vellykkede forsøk med subkutane injeksjoner av testikkelsaft (organoterapi) (35). Det ble også gjort kliniske forsøk med subkutan nervetranfusjon, der injeksjonsvæsken var fremstilt av grå substans fra hjernen til en nyslaktet sau, med gode resultater (36). Og i et norsk bidrag basert på Brown-Séquards prinsipper, beskrev Hans Jørgen Vetlesen (1852-1926) egne forsøk med fosforsurt natron i behandlingen av nevrastenikere. Fosforsurt natron skulle ha testikkelsaftliknende egenskaper, og Vetlesen observerte god effekt av dette preparatet hos sine pasienter (37).

Den minst kontroversielle og mest effektive behandlingen av nevrasteni var nok likevel den forebyggende (24). «Eksogen» nevrasteni kunne blant annet forebygges ved god ernæring, avhold fra alkohol, moderat og variert arbeid samt gradvis tilvenning til arbeid og andre aktiviteter $(15,20)$. Ved «endogen» nevrasteni var oppmerksomheten blant annet rettet mot generelle hygieniske spørsmål, som bekjempelse av tuberkulose, kjønnssykdommer og alkoholisme. Dette skulle redusere antallet på «dem som i en kachektisk tilstand sætter et mindreværdig avkom i verden» (24).

\section{Prognose}

Prognosen ved nevrasteni var avhengig av alvorlighetsgrad, varighet og til dels utløsende årsak, men ble hyppigst beskrevet som god. For de mildeste formene av tilstanden kunne fjerning av utløsende årsaker og noen få dagers hvile og skjerming være tilstrekke- lig for full helbredelse $(13,15)$, og flere sanatorieleger rapporterte om oppløftende resultater. Eksempelvis ble det fra Hankø Bad og Kystsanatorium i perioden 1885-87 rapportert at av 82 tilfeller ble 36 helbredet, 26 betydelig bedret, 17 bedret og bare tre viste seg uhelbredelige (38). Ved Modums Kuranstalt og Sanatorium 1881-85 var resultatene også gjennomgående gode; av 283 pasienter hadde hele 247 et gunstig resultat av behandlingen (19).

Andre leger var noe mindre optimistiske, deriblant Johan Karl Unger Vetlesen (18511914) ved Grefsen Vandcuranstalt. Han advarte mot tilbakefall og understreket at nevrasteniens «lunefulde Karakter og langsomme Forløb» tilsa at kortvarige enkeltkurer sjelden ville være tilstrekkelig (10). Vogt påpekte en annen skyggeside ved nevrasteniens prognose, nemlig at tilstanden kunne utvikle seg til mer alvorlig sykdom; for eksempel psykoser (15). Generelt hadde pasienter med den antatt hereditære formen for nevrasteni dårligst prognose (27), noe de innrapporterte tallene fra Valen også peker mot. 


\section{Utbredelse}

Selv om legene var uenige om hvorvidt nevrasteni var en ny sykdom, synes det å ha vært enighet om at forekomsten av tilstanden økte spesielt mot slutten av 1800-tallet $(13,27)$. Det totale omfanget av nevrasteni i Norge kan selvsagt ikke bestemmes bare ut fra materialet denne artikkelen baserer seg på, men diagnoselister og statistikker fra kursteder, sanatorier og andre relevante behandlingsinstitusjoner viser at diagnosen ble stilt forholdsvis ofte i perioden 1880-1920. Særlig ved kurog badestedene forekom nevrasteni som en hyppig diagnostisk kategori. Eksempelvis favner kategorien «Nervøsitet og Neurastheni» ved Hankø Bad og Kystsanatorium 49 pasienter allerede i perioden 1882-84 (14), ved Laurviks Bad ble 249 pasienter behandlet for nevrasteni i løpet av en treårsperiode (1883-86) (39) og ved Grefsen Vandcuranstalt 171 pasienter i løpet av somrene 1884 og 1885 (10). I 1913 uttrykte Harald Arnesen bekymring for overdiagnostisering og over at diagnosen hadde blitt for populær: «Ordet neurastheni har slaat an hos det store publikum; det er noget visst elegant ved at være litt neurasthenisk, og det er en eleganse, som er paa moden» (40).

Det er grunn til å anta at flertallet av nevrastenipasientene ved norske kursteder kom fra bedrestilte klasser. Nevrasteni er også tradisjonelt blitt betraktet som en «overklassesykdom» (4), men ifølge flere norske leger kunne mennesker i alle sosiale lag rammes $(11,18)$. Likevel ble enkelte yrkesgrupper regnet for å være mer utsatt enn andre, som «åndsarbeidere» og travle forretningsmenn (12). Fra Amerika ble det rapportert at tilstanden også forekom særlig hyppig blant leger (13).

Mens det særlig var kvinner som ble diagnostisert med sammenliknbare tilstander som hysteri og klorose, var for eksempel hele 161 av de 171 nevrastenikerne ved Grefsen 1884-85 menn (10), og i flere av de øvrige kurberetningene er det rapportert om en andel mannlige nevrastenikere på 30-60\%. Dette stemmer med inntrykket i den internasjonale litteraturen, der nevrasteni gjerne fremstilles som en sykdom som vel så ofte rammet menn som kvinner. Denne litteraturen er imidlertid ikke samstemt. Funn fra Sverige viser at flere kvinner enn menn fikk diagnosen, og at sykdommen var kvinnelig konnotert (41).

\section{Oppsummering og konklusjon}

Nevrasteni ble en stadig hyppigere anvendt diagnostisk kategori i Norge utover 1880- årene. Mens det tidlig i perioden først og fremst var leger ved kur- og badesteder som skrev om tilstanden, finner vi etter 1900 flere psykiatere blant forfatterne. Nevrasteni ble definert som svekkelse av nervesystemet. Hovedsymptomet var utmattelse, gjerne ledsaget av andre symptomer som hodepine, fordøyelsesbesvær, søvnløshet, nervesmerter og hjertebank. Årsakene kunne ikke verifiseres eller lokaliseres objektivt, men teoriene var mange. Overanstrengelser av ulike slag ble regnet som den vanligst utløsende faktoren. Den anbefalte behandlingen dreide seg om å styrke nervesystemet, blant annet gjennom hvile og elektrifisering. Prognosen var generelt god, men uhelbredelige tilfeller ble også omtalt. Tilstanden ble beskrevet som typisk for sin tid, som en respons på «tidsånden» og det moderne liv.

\section{Kristine Lillestøl (f. 1978)}

er lege og postdoktorstipendiat. Forfatter har fylt ut ICMJE-skjemaet og oppgir ingen interessekonflikter.

\section{Hilde Bondevik (f. 1963)}

er idéhistoriker og førsteamanuensis.

Forfatter har fylt ut ICMJE-skjemaet og oppgir ingen interessekonflikter.

\section{Litteratur}

1. Die Neurasthenie. Bokomtale. Norsk Mag Lægevidensk 1886: 47: 223-24.

2. Beard GM. Neurasthenia, or nervous exhaustion. Boston Med Surg J 1869; 3: 217-21.

3. Beard GM. A practical treatise on nervous exhaus tion (neurasthenia): its symptoms, nature, sequences, treatment New York, NY. William Wood \& Co 1880

4. Wessely S. Old wine in new bottles: neurasthenia and 'ME'. Psychol Med 1990; 20: 35-53

5. ICD-10. Norsk utgave. Oslo: Helsedirektoratet, 2011.

6. Leone SS, Wessely S, Huibers MJH et al. Two sides of the same coin? On the history and phenomenology of chronic fatigue and burnout. Psychol Health 2011: 26: 449-64.

7. Johannisson K. Melankoliska rum. Om ångest, leda och sårbarhet i förfluten tid och nutid. Avesta: Bonnier, 2010

8. Malthe. Bidrag til terapien af neuroser. Norsk Mag Lægevidensk 1876; 37: 826-29.

9. Holm IC. Balneologiske studier. Beretning fra Laurviks Bad for 1880-82. Norsk Mag Lægevidensk 1883; 44: 49-73

10. Unger-Vetlesen JK. Grefsen i 1884 og 1885. Norsk Mag Lægevidensk 1886; 47: 190-97.

11. Torp JKG. Fra Doktor Torp's Sygehjem for Nervesvækkede paa Lillehammer. Norsk Mag Lægevidensk 1886; 47: 658-69.

12. R.C. Om neurasteni og dens behandling. Medicinsk Revue 1889; 6: 311-17.

13. St. Uddrag. Neurasthenia. Tidsskr Prakt Med $1885: 45: 428-31,438-45$
14. Magelssen A. Treaars-Beretning fra Hankø Bad og Kystsanatorium. Norsk Mag Lægevidensk 1885; 45: 202-19.

15. Vogt R. Psykiatriens grundtræk. Kristiania: Steenske Bogtrykkeri og Forlag, 1905.

16. Bøe G. Om behandlingen av neurastenie. Medicinsk Revue 1907; 24: 494-96.

17. Grieg L. Neurastenisk gastrointestinal atoni. Medicinsk Revue 1893; 10: 333-34.

18. Bull E. Om nervøsitet. Foredrag. Kristiania, 1891

19. Dedichen HGS. Femaarsberetning (1881-85) for Modums Kuranstalt og Sanatorium. Norsk Mag Lægevidensk 1886; 46: 249-61.

20. Torgersen P. Varig skade paa helbreden forvoldt ved idrætsøvelse. Norsk Mag Lægevidensk 1915; 76: $37-43$

21. Winther G. Kunstig sterilisering av kvinden ved cerebrale sygdommer. Medicinsk Revue 1920; 37: $39-41$.

22. D. Til bedømmelsen af den vegetariske diett. Medicinsk Revue 1901; 18: 240-49

23. Broch-Martens. Om autointoxikationens forhold til neurasteni. Medicinsk Revue 1896; 13: 245.

24. Andresen KA. Nervøsitetens aarsager og bekjæmpelse. Medicinsk Revue 1910; 27: 143-48.

25. Vogt R. Nervøse reaktioner. Tidsskr Nor Lægeforen 1917: 37: 729-52

26. Arnesen H. Psychiatri i krig. Medicinsk Revue 1915: 32: 477-93

27. Torp JKG. Dr. Torps sygehjem. Tidsskr Nor Lægeforen 1894; 14: 489-501.

28. Bøe G. Liggekur i teori og praksis. Medicinsk Revue 1913: 30: 256-58.

29. St. Uddrag. Virkningen af faradiske og galvaniske Bade. Tidsskrift for Praktisk Medicin 1883; 3 : 168-69.

30. Rode E. Lidt om elektriske Bade. Tidsskrift for Praktisk Medicin 1883; 3: 161-7.

31. Holm IC. Om klima og klimatisk behandling. Tidsskr Nor Lægeforen 1906; 26: 329-39.

32. Sadolin F. Erfaringer og overveielser vedrørende arbeidsterapi. Tidsskr Nor Lægeforen 1906; 26: 417-21.

33. Strømme J. Die Psychanalyse und ihre Technik. Tidsskr Nor Lægeforen 1917; 37: 1-10.

34. Arnesen H. Valen asyl 1910-1915. Medicinsk Revue 1916; 33: 23-49.

35. Hansen GA. Terapeutisk anvendelse af injektioner af testikelsaft. Medicinsk Revue 1890; 7: 151-62.

36. Hansen GA. Fortsatte meddelelser om behandlin gen af neurasteni, melankoli og epilepsi med injektioner af normal nervesubstans. Medicinsk Revue 1893; 10: 153-54

37. Vetlesen HJ. Fosforsurt natron ved nevrastheniske tilstande. Norsk Mag Lægevidensk 1907; 68 : 345-56.

38. Magelssen A. Anden Treaarsberetning fra Hankø Bad og Kystsanatorium for Aarene 1885-87. Norsk Mag Lægevidensk 1888; 49: 305-25.

39. Holm IC. Balneologiske Meddelelser. Laurviks Bad for 1883-1886. Norsk Mag Lægevidensk 1887 48: $269-78$

40. Arnesen H. Begrepet neurastheni. Medicinsk Revue 1913; 30: 548-52.

41. Johannisson K. Det mørke kontinentet: Kvinner, sykelighet og kulturen rundt århundreskiftet. Oslo: Aventura, 1996

Mottatt 18.10. 2012, første revisjon innsendt 11.2. 2013, godkjent 14.2. 2013. Medisinsk redaktør Are Brean. 